\title{
What Plants and Animals Do Early Childhood and Primary Students' Name? Where Do They See Them?
}

\author{
Patricia Patrick $\cdot$ Sue Dale Tunnicliffe \\ Published online: 9 April 2011 Ó Springer Science+Business Media, LLC 2011
}

Abstract Children from England and the United States of America have a basic similar knowledge of plants and animals, which they observe during their everyday life. Nine children of ages $4,6,8$, and 10 years, in each country, were asked to free-list plants and animals. Afterwards, they were interviewed individually about the plants and animals they listed to determine where they were seen. Addition- ally, children were asked to name animals they knew that were found in specific habitats or had specific character- istics. The results showed that children from the earliest years notice the animals in their everyday lives and 8 year olds were able to name the most animals. Plants were not named as often as animals and children in the USA found it difficult to name plants when questioned. This study shows that children are in touch with their everyday environment to varying extents, and that rich experiences can greatly contribute to their knowledge about plants and animals.

Keywords Early childhood $\square$ Primary students $\square$ Informal learning $\square$ Knowledge of plants and animals $\square$ Habitats $\square$ Organisms

P. Patrick (\&) College of Education, Texas Tech University, Box 41071, Lubbock, TX 79409, USA e-mail: trish.patrick@ttu.edu; mydogmack@hotmail.com

S. D. Tunnicliffe Department of Geography, Enterprise, Mathematics and Science, Institute of Education, University of London, 20 Bedford Way, London WC1H 0AL, UK e-mail: s.tunnicliffe@ioe.ac.uk

\section{Introduction}

Even though the USA and England are similarly devel- oped countries, they may have differing relationships with organisms in their everyday lives. This study is an international look at the differences in the knowledge of children ages 4, 6, 8 and 10 years old. An international study is important because it provides an opportunity to determine the differences in children's knowledge of organisms. This difference is important because it may lead to questioning and determining if there is a cultural or educational (formal and informal) difference in what children 
know about plants and animals. For example, if children in England name more farm animals than children from the USA then it is important to do further studies to determine if these differences are due to education or culture. These differences may also point to the lack of a relationship with the environment (Louv 2006).

Children encounter some organisms or representations of organisms in their daily lives. For example, at school children have indirect contact with animals through classroom decorations. School also provides children with direct contact with domestic, farm and exotic animals through school field trips to museums, farms, zoos, and field/nature centers (Tunnicliffe et al. 2007; Tunnicliffe 1999).

Additionally, the direct interactions children have with classroom pets have been found to influence chil- dren's ideas concerning animals (Prokop et al. 2007, 2008).

Conversely, research shows that experiences outside of the school are an important source of science literacy (Bell et al. 2009; Falk and Dierking 2010; Lucas 1991). Driver et al. (1994) explained that children develop a theory about natural phenomena before they experience

\section{3}

J Sci Educ Technol (2011) 20:630-642

631

any formal teaching. Therefore, real life, out-of-school experiences are paramount to learning about organisms. For example, keeping pets (Prokop et al. 2007and playing in a creek are important real life experiences (Vadala et al. 2007). Significant experiences in the wild often lead to involvement in environmental conservation in adult- hood (Tanner 1980). Moreover, Palmer (1993) describes how concern about the environment develops through formative, nature-based experiences. As children develop their knowledge of the natural world, through nature- based encounters, children cultivate their attitudes and concern towards nature. Children do have knowledge of nature (Carey 1985; Helm and Novak 1983; Metz 2010; Osborne and Wittrock 1983; Piaget 1983).

Even though knowledge in and of itself does not insinuate understanding, it frames our ability to evaluate and incorporate new ideas and experiences (Davenport and Prusak 1998). Moreover, knowledge is shared through (1) observation, imitation, and practice (Socialization); (2) verbalization and diagrams (Internalization); (3) models, hypothesis, and language (Externalization); and exchanges of information through conversations (Combination) (Nonaka and Takeuchi 1995). Moreover, the 
constructivist idea of knowledge states that all learning is based on personal processing of information (Fraser and Tobin 1998), takes place within a context of social interaction, and is influenced by culture, personal interactions, and language (Solomon 1987). Therefore, if knowledge is defined as the ability to evaluate ideas and share them through observation, verbalization, hypothesizing, and conversation then we propose that children's knowledge of plants and animals may be ascertained through inter- views. Moreover, determining children's plant and animal knowledge by asking them to talk about where they have seen the organisms builds on Eshach's (2006) idea of social situations and participation as a link to learning. By determining children's ability to name and provide locations for plants and animals we determine that children learn mostly at home (i.e. informal and social situations). This base knowledge can then be used by teachers to design their lessons when teaching more abstract ideas concerning the interactions of plants and animals. This study incorporates free-listing and interviews to ascertain what children know about the natural world by determining their ability to name and describe the locations of plants and animals. The study will ask the following questions: (1) With which plants and animals are children familiar? (2) Which animals do children notice in their everyday environment? (3) What are the locations at which children say they observe plants and animals? and 4) From where have the children gleaned their knowledge about plants and animals?

\section{Theoretical Framework}

The USA National Science Standards (National Research Council 1996) state that children, ages five to ten, should be able to identify organisms and their characteristics, life cycles, and habitats. England's National Curriculum pro- vides a bit more detail. The English Curriculum states that children should relate life processes to organisms in the local environment, recognize similarities among organ- isms, group organisms based on their characteristics, identify the organisms in their local environment, and care for the local environment (England National Curriculum 2011). These science curriculums require children to know organisms and their characteristics, including their habitats. Therefore, it is imperative that when children enter school teachers have a clear understanding of children's knowl- edge of plants and animals. This study initiates a look at the baseline knowledge of children as they begin school.

In countries where children and adults are out of touch with the natural world, the general public has a low level of awareness about local environmental issues, a poor understanding of ecosystems, and a general lack of care and apathy for the environment (Evans et al. 2007). Louv (2006) blames the technological age for the loss of our development of environmental and biological awareness. Prior to the current digital age, children developed their understandings of the natural world 
through books, per- sonal observations, storytelling and their parents and grandparents. However, schools are not highly ranked as a source of information concerning the natural world (Gatt et al. 2007; Reiss and Tunnicliffe 1999; Tunnicliffe and Reiss 2000). In fact, children, in developed countries, are acquiring their information about the natural world second hand through the media (Pergams and Zaradic 2006, 2008; Zaradic and Pergams 2007).

Children do not come to the classroom as a blank slate. They have personal experiences, which they bring to the classroom. However, children's ideas about nature are not always correct. Therefore, teachers must be aware of children's knowledge concerning the natural world and the children's misconceptions (Tull 1992) and restructure their teaching. Simply adding information to children's existing knowledge does not change their mental con- structs (Osborne and Wittrock 1983). Teachers do not address prior knowledge, because they use a restrictive range of resources (Sanders 2007), use a narrow view of the organisms they teach, have a lack of confidence (Braund and Reiss 2004) in their science knowledge (Osborne et al. 1998), and feel hindered by the demands placed on them by testing (Keiler and Woolnough 2002; Krueger et al. 2002; Reiss and Tunnicliffe 1999; Toplis and Cleaves 2006).

\section{3}

632

J Sci Educ Technol (2011) 20:630-642

\section{Children's Conceptions of Plants}

Plants are important to humans and the consumption of plants is increasing. Sanders (2007) states that a loss of biodiversity and the demands humans place on the envi- ronment are important environmental reasons humans should consider plants. Moreover, modern societies are blind to the value and nature of plants (Schneekloth 1989). In 2010, the earth's human population was 6.8 billion and rising (Population Connection 2010). The rise in global population is responsible for diminishing green areas and triggering the demand for produce and trees to rise to unprecedented levels (Fujiwara and Matoh 2009). Twenty- five of the best selling pharmaceuticals originate from plants (BGCI 2010a). The demand for plants has caused an over-exploitation of plant species, which is the most significant cause of extinction (BGCI 2010a). Today, approximately $25 \%$ of plant species face extinction, posing serious and life threatening consequences for all life on earth (BGCI 2010b). Plant decline is an important aspect of teaching, because the food sources, green areas, and pharmaceuticals we need to survive are being depleted. Therefore, teachers need to involve pupils in discussing 
controversial issues, such as deforestation, genetically engineered crops, and the use of plants to manufacture pharmaceutical drugs (Braund and Reiss 2004). The good news is that the educational institutions possess the power to change the way children think and feel about real-world issues (Richardson and Blades 2001).

Young children, worldwide, have an innate interest in plants, but as they grow older their attitudes change and they do not notice plants and do not believe plants have value (Schneekloth 1989). This phenomenon of ignoring plants as if they are not there is referred to as plant blindness (Wandersee and Schussler 2001). However, plant blindness should not be an issue in a country such as England, where approximately 20 million households have a garden (Braund and Reiss 2004). In fact, gardening is listed as the British citizens' most favorite pastime (Sanders 2007). Yet, plant blindness is a concern. Children do not find any value in learning plant names Bebbington (2005) and plants on display at places of informal learning are ignored (Braund and Reiss 2004). Plants are not given the wonderful, exciting descriptions placed on animals. Plants are described as immobile, faceless objects with a non-threatening presence, which causes the public to view them as inconsequential (Wandersee and Schussler 2001). Such unremarkable attributes have given rise to the com- mon belief that plants are inferior to animals. Teachers, who spend more time focusing on the animal kingdom, further invoke these plant misconceptions. Teachers of the biological sciences have been labeled "zoochauvinists" (Hershey 1996), because they allow their teaching of

animals to overshadow plants. Overlooking plants in the curriculum is easy for teachers, due to children's disinterest (Sanders 2007). Even though, plants are an important part of the ecosystem, they are essentially neglected in the classroom (Barman et al. 2006; Tunnicliffe and Reiss 2000). Two reasons that botaniphobia and a lack of plant knowledge and care have evolved are: (1) Research shows that the human brain picks out movement around the immediate environment; therefore, it may be that immo- bile, non-threatening plants do not gain our attention (Strgar 2007). and (2) Because humans are animals, this may trigger an innate interest in other animals (Tunnicliffe 2001).

Even though teachers find it difficult to maintain pupils' interest in plants, lessons that are engaging and promote long-term learning have the potential to raise interest and appreciation (Lindemann-Matthies 2005). For example, teachers should use real plant and animal specimens to teach similarities and differences (Tunnicliffe 2001). Les- sons have been developed that show the interdependence of plants and animals and plant growth (e.g. Amsel 2009; Jones 2009; Quinones and Jeanpierre 2005). These lessons offer a more in-depth and relevant botany context.

Little research is available concerning young children's ideas concerning plants 
and their understandings of the concept 'plant' (Boulter et al. 2003; Tunnicliffe 2001; Tunnicliffe et al. 2008). Instead, research in children's understandings of plants has focused on their knowledge of plant growth and photosynthesis (Barman et al. 2006; Russell and Watt 1990; Osborne et al. 1992). As early as the 1970's, research has documented the lack of United States children's plant knowledge in comparison to the plant knowledge of children in other countries (Dougherty 1979). Additionally, research within the United States has shown (1) a significant difference in plant knowledge between children and their parents and grandparents (Nabhan and Antoine 1993; O'Brien 2008), and (2) that elementary and college students have a low level of spe- cific plant knowledge, especially wild plants (Cooper 2008; Wagner 2008). In Brazil Natarajan et al. (2002) found that tribal students, ages 10-15 years, have a base knowledge of plants that is richer in ecological content than the plant knowledge of urban students. Chitra, et al. showed that simply having plants in the environment did not make students aware of plants. Even though the literature shows that there are some differences in children's plant knowl- edge regionally or culturally (Bebbington 2005; Bell 1981), children worldwide still share common beliefs about plants. For example, a common misconception held by children worldwide is that the plant is not a living entity (Stavy and Wax 1989).

Young children do not recognize plants as living things and construct their own ideas about natural phenomena,

\section{3}

J Sci Educ Technol (2011) 20:630-642

633

based on their sensory and personal interactions with their environment (Tunnicliffe 2001). Additionally, children use their own strategies to identify plants (Uno 2009). There- fore, it is essential that children have direct interactions with plants to make a significant difference in their knowledge (Askham 1976). This study elicits the knowl- edge children acquire from their everyday lives and from where they believe they acquire the knowledge. Therefore, the aim is to determine what children intuitively think of as a plant and an animal and ascertain where that source of knowledge is acquired.

Children's Conceptions of Animals

From their earliest moments, children are learning about animals and plants (Keil 1979). Children are introduced to animals in their everyday lives through encounters with animal images at home and in the media (Tunnicliffe et al. 2008). 
Additionally, they have personal interactions with animals as pets (Prokop and Tunnicliffe 2008) and as livestock, which are kept for meat, milk, eggs, honey, and transport. Animals are featured in various ways depending on the culture. Children in developed countries come in contact with animals in gardens, parks, zoos, forests, farms, and nature centers, which may allow them contact with exotic animals. In less developed countries the local ani- mals are as much a part of the lives of the inhabitants as the children. The children from these countries have an eco- logical understanding of animals superior to that of chil- dren from developed countries (Bang et al. 2007). However, worldwide children have the same difficulties in learning about the life histories, adaptations, and habitats of animals (Atran and Medin 2008).

The opportunity for exposure to wild and exotic animals is mostly limited to visiting a zoo. In fact, teachers and parents believe that the primary reason for visiting a zoo is for the educational benefit of children. However, zoo vis- itors' knowledge of animals has been shown not to be significantly different from those of non-visitors (Kellert 1980). Tunnicliffe (1996) determined that when children look at animals in exhibits, they mention anatomical fea- tures such as the size, shape and color. They do not men- tion conservation issues or habitat. People who belong to wildlife and/or environmental organizations or watched animal-related television programs are more likely to have knowledge of animals, conservation issues, and habitat (Ascione 1992; Kellert 1980). The issue is that animals in zoos and museums do not provide a realistic view of the natural world, because they are not diseased or suffer from malnutrition. Animals are shown as healthy and physically fit (Reiss et al. 2007). These are not natural situations in which children may learn about the reality of animals'

lives. Therefore, activities geared toward wildlife in their natural environments are important in the development of knowledge (Eagles and Muffitt 1990; LaHart 1978; West- ervelt and Lewellyn 1985).

Compared with adults, young children should possess a different understanding of animals. However, there may only be slight differences in their knowledge. Young children are concerned with shape, form and size (Braund 1998) and employee anthropomorphic terms in their explanations (e.g. Carey 1985). Prokop and Tunnicliffe (2008) found that elementary school children did not have positive attitudes towards bats and spiders. Children were more negative towards the spider than the bat, but this could be because they had more interactions with spiders. Shepardson (2002) have determined that 5-11 year olds understand how insects feed, their locomotion, and their physical characteristics, such as size and shape. Tunnicliffe and Reiss (1999) have discovered that young children rely on anatomical structures to group animals, while older children use taxonomy, habitat and behavior in addition to anatomical structures. Cardak (2009) has explored 
preser- vice science teachers' understandings of birds. He uncov- ered at least 10 misconceptions. For example, preservice teachers stated that a bat is a bird and a penguin is a fish or mammal. Prokop and Rodak (2009) established that when identifying birds "elementary school pupils and biology majors did not significantly differ (p.131)." Furthermore, they stated "This supports the idea that knowledge of biology on this topic is rapidly acquired before the age of 10 (Carey 1985; Jaakkola and Slaughter 2002) and further acquirement is somewhat slower (p. 131)." Therefore, it is important to focus on animal study in the early childhood classroom or at the very least to determine what children know about animals at the early childhood level and pri- mary level. Educators must be cognizant of these findings and mindful that children bring their own mental concepts and ideas of animals, which they have built from previous experiences.

Children learn to identify organisms from the everyday names used within the culture in which they are living (Brown 1958; Rosch and Mervis 1975). Consequently, listening to children talking about their own experiences, interests, and knowledge is an important aspect of under- standing the cultural roles in defining their mental models (Tunnicliffe et al. 2007). Furthermore, naming organisms allows children to make sense of the world around them and provides opportunities for discussion and inquiry (Tunnicliffe 2001). This international study uses language to determine the development of children's abilities to name plants and animals, name animals in particular hab- itats, the students' sources of information, and cultural perspectives.

\section{3}

634

J Sci Educ Technol (2011) 20:630-642

Methodology

In order to better understand children's plant and animal knowledge, this research focuses on differentiating between types of knowledge like naming the organism and determining where it has been seen. For example, deter- mining that a child can say the word "tree" when asked to name a plant may not define their level of knowledge. Therefore, it is important to probe the child's knowledge by asking them to tell where they saw the plant. Addi- tionally, asking children to name plants found in certain habitats may be useful to glean knowledge that was not otherwise available by only asking them to name plants. Asking probing questions such as, "Can you name a plant that lives in water?" and "Where did you see that plant?', may produce an argument for identifying key childhood experiences, in which learning about the natural world takes place. Exploring where children see 
plants and ani- mals and the plants or animals children associate with different habitats, may underscore the importance of childhood place-based experiential education programs into school curriculum.

Many different methods have been employed to determine salient themes in children's perceptions. Studies have used open questioning (Dikmenli 2010), preand post-test techniques (Haslam and Treagust 1987), concept mapping (Novak 1990; Novak and Gowin 1984), draw- ings (Bahar et al. 2008; Erdogan and Erentay 2007; Kose 2008; Prokop and Fanoviova' 2006; Prokop et al. 2009; Reiss and Tunnicliffe 2001; Reiss et al. 2002; Teixeira 2000), and a word association questionnaire based on keywords (Cardak and Dikmenli 2009; Sato and James 1999; Torkar and Bajd 2006). The data collection for this study is a structured three-layered interview. The first layer uses free-listing and asks children to list all the organisms they know in $1 \mathrm{~min}$. The second layer asks children to state where they saw the organism. The third layer provides children with a habitat and asks them to identify an organism found in that specific habitat. For example, "Name an animal that lives in the water." The three-layer approach is important, because asking children to name organisms does not provide information con- cerning their knowledge constructs. Children may be repeating names they have heard others use. They may have no deeper understandings of organisms. However, asking children to describe where they saw the organism provides a reference point to determine the relationships children see between organisms and habitats. Addition- ally, if children are asked to name organisms living in specific habitats and they are not able to provide answers, this may mean that they are not able to cognitively determine environmental relationships between organisms and habitat.

This study included 108 early childhood and primary school children. Seventy-two were from England and thirty-six were from the United States (US). Nine children, in each of four age groups, were chosen for this study by preschool and classroom teachers, who had each had more than 7 years of experience. Teachers of 4, 6, 8 and 10 year olds were asked to choose three children from each of the following abilities: low, middle and high. The teachers were asked to select as equal as possible a distribution of males and females. The study was limited to nine children in each age level, because this study was unfunded and it proved difficult to find teachers who would allow children to miss class instruction. The number of children was greater in England than the US, because the same 36 children were employed in the US study for both the plant and animal interviews, whereas, 72 children were in England study, because a different set of children partici- pated in the plant interviews than those interviewed con- cerning their animal knowledge. The English schools were located in North London. The US schools were located in a metropolitan area in central North Carolina. The selection of settings was purposeful in that children would have similar interactions with the natural world. For example, it would not make sense to interview children from a metropolitan 
area and a rural area, unless they were from the same country.

Research data was collected by conducting structured interviews (Figs. 1,2) with 72 English children and 36 US children. The English interviews were conducted by one of the authors. The US interviews were conducted by the author's second year research assistant, who had been trained in interviewing techniques and the interviews used in this study. Children were interviewed separately in a quite location within the school. The same 36 US children were interviewed to gather the plant and animal data. However, the plant interview and animal interview were done on different days. The same children were not available for the England interviews. Therefore, for the England interviews 36 children were interviewed for plant data and 36 children were interviewed for the animal data.

Prior to the interviews, the researchers told the children they were interested in determining their ideas concerning plants or animals. The researchers assured the children that all of their answers were acceptable and no right or wrong answers existed. Technical biology terms such as inverte- brate were explained as necessary during the interviews.

Data Analysis and Results

The data presented here exemplify the overall findings and give some indication of the different cultural influences on English and US children's knowledge. After the data sheets

\section{3}

J Sci Educ Technol (2011) 20:630-642

635

Fig. 1 Questions asked during the plant interview

Child's Age:

Ask children the following questions. For number one, make sure to allow children one minute to answer. Write children's answers below each question.

1. Name as many plants as you can (give students one minute).

2. Where did you see the ? (Name each plant and ask the student where they saw it.)

3. Tell me what plants live here at school? Where have you seen them?

4. Tell me what plants live around your home? Where have you seen them?

5. For each of the following ask the student if they can name a plant in that category and ask them to name the places they have seen it (e.g. TV, books, garden, etc.). 


\section{Category}

Plant Named

Location

I

I

I

In garden

1
1

Inside house 
Outside house

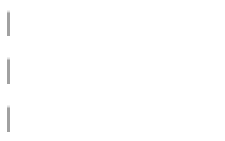

Has flowers

Is green but does not have flowers

Lives no walls 
Lives on water

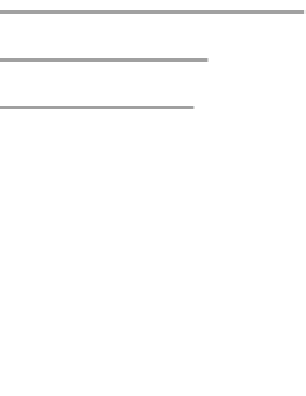

Lives in water

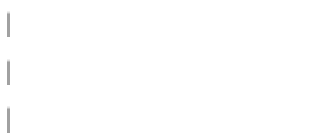

Seen insects on it

Smells/Has a smell

| 
You may eat it

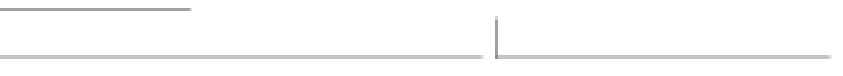

Lives on the ground

were read and the data was placed in an Excel file, cate- gorical responses emerged. The plants and animals named by the pupils in 1 min were grouped in the following categories: Exotic (to that country), Endemic Wild, Domesticated for Pleasure, and Farmed. Additionally, the plants and animals named in $1 \mathrm{~min}$ were divided by using a scientific identification, which was developed by the authors. The plants were divided into Bryophytes, Vascular Seedless, Gymnosperms, Monocots, and Dicots. The animals were divided into Mammals, Birds, Reptiles, Amphibians, Fish, Arthropods (Arachnids), Arthropods (Insects), Mollusks, and Annelids. The children's responses to where the plants and animals were seen, were dispersed into the following

categories: Zoo, Media, Pet Shop (Shop/Store for plants), School, Outside, Home/Garden/Yard, and Visit to Natural Area. To determine if children were able to make connec- tions, the interviewers asked the children to name a plant or animal based on its characteristics or habitats.

A qualitative analysis approach was taken, because there was not enough data to perform a quantitative analysis. Even though the data is presented quantitatively, statistical analyses were not possible. The children's responses for each question were placed into an Excel file and totaled. In question number one all the answers were counted sepa- rately, unless a child named the same organism twice. For example, if a child named a cat, lion, dog, blue jay, seagull,

\section{3}

636

J Sci Educ Technol (2011) 20:630-642 
Fig. 2 Questions asked during the animal interview

Child's Age:

Ask children the following questions. For number one, make sure to allow children one minute to answer. Write children's answers below each question.

1. Name as many animals as you can.

2. Where did you see the ? (Name each animal and ask the student where they saw it.)

3. Tell me what animals live here at school? Where have you seen them?

4. Tell me what animals live around your home? Where have you seen them?

5. For each of the following ask the student if they can name an animal in that category and ask them to tell the places they have seen it (e.g. TV, books, garden, etc.).

\section{Category}

\section{Animal Named}

\section{Location}


A small mammal

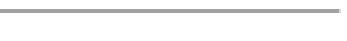

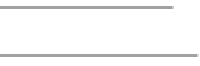

I

I

A domestic animal

A flying invertebrate

A walking invertebrate

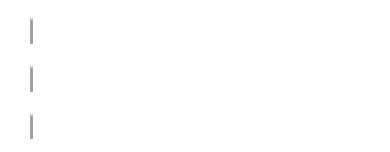


An invertebrate that lives in the ground

Lives in water

Lives on water

Nocturnal animal

and bird; they received a total count of five for the animals named. The word "bird" was not counted, because the blue jay and seagull are examples of birds. Question number two asked children to tell where they saw the animal. All data points were counted separately. For example, if a child said they saw the cat-home, lion-TV, dog-home, blue jay- home, seagull-beach, and bird-school, they received the following counts: 3-home, 1-media, 1-visit to natural area, and 1-school. The "bird" data was counted in this data, because it was a different location than the others. Each location or characteristic listed in question number five was coded once for the plant or animal named. Therefore, none of the answers would have a count of more than nine, because only nine children were interviewed for each. However, when children were asked where they saw the organism, they may have answered "the grocery store",

"my backyard", and "at school". Each of the previous answers would have been 
counted; therefore, an answer for where the children saw the organism could have a total of more than nine. If a child answered, "I don't know" the answer was not coded.

Plants

Even though the total number of plants named by children in England (154) and USA (126) were similar, domesti- cated plants were named by children in England (58) more than exotic (9), endemic wild (49), and farmed (50) (Table 1). Children in the USA named farmed plants (47) more often than exotic (7), endemic wild (38), and domesticated (33). When the plants named by children were broken down into scientific categories the results for

\section{3}

J Sci Educ Technol (2011) 20:630-642

637

Table 1 Total number plants named in 1 min and where they were seen

Category of plants named by children

Age of students Exotic (to the country) Endemic wild Domesticated for pleasure Farmed Total

Country

USA

4 years $1 \quad 3 \quad 1$

6 years $2 \quad 7 \quad 5$

8 years 10 years $31 \quad 1217 \quad 1215$

England

Total 4 years 71399333

6 years $4 \quad 5 \quad 13$

years

Where plants were seen Zoo Media 0 Shop/store 0 School 0 Outside 0 Home/garden/yard 3

Visit to natural area (beach, park, woods, etc.) 0 
$\mathrm{N}=9$ for each age group in each country

8 years 10 years

England Total 4 years

8 years 10

years

27 USA 4 years 0000000000

1024

6 years

$\begin{array}{ll}0 & 12\end{array}$

$0 \quad 2$

$3 \quad 1$

$0 \quad 3$

$10 \quad 38$

$\begin{array}{ll}5 & 12\end{array}$

325

6 years

21230046002602251344596217193633

13224055

471629

Total 9495850

Total

347381111013973329429951223

8 years 10131025161412193961

the two countries were nearly the same. Dicots (England- 124, USA-99) and monocots (England-23, USA-35) were named more often than any other type of plant (Table 2). The most frequently named dicot was the rose. The most frequently named monocot was grass. Bryophytes were not identified by children in the US, but four bryophytes were named in England. Plant knowledge increased with age in both countries, except for the slight decrease in English data between 4 and 6 year olds (Table 1). All age groups identified home/garden/yard (England99, USA-96) as the location they see plants most often. School was mentioned as the fourth location in England (13) and fifth in USA (6). Zoos were not named as a 
place to see plants. The chil- dren's ability to name plants when provided with a habitat did increase with age (Table 3) and home/garden/yard remained the number one place to see plants.

Animals

The results indicated that the English children were more likely to name exotic animals (191), while the USA chil- dren were more likely to name endemic animals (149) (Table 4). Eight year olds in England (132) and USA (134) identified more animals than any other age groups. The frequency of pets/domesticated animals (England-63, USA-67) were similar in both countries. Additionally, the children listed farm animals less than any other group (England46, USA-30). Animals were seen in the media, at home/garden/yard, at the zoo, and at school (Table 4). Vertebrates were cited more often than invertebrates (Table 5). The most named scientific category was mammals

(England-224, USA-284). The invertebrates encountered everyday were mollusks, arachnids (all spiders) and insects. Children in the USA found it difficult to name a flying invertebrate (1) (Table 6) and animals that live on water (2). Even though 8 year olds named more animals in 1 min than any other age group, 10 year olds were more likely to cor- rectly identify an animal when asked about habitat and characteristics (Table 6).

\section{Conclusions and Discussion}

The English and USA national curriculums state that children must understand organisms and their habitats and how organisms are important in the local environment. Understanding children's knowledge of the characteristics, habitats, and locations of everyday plants and animals is the beginning of understanding children's zoological, ecological and environmental knowledge. Even though much attention has been afforded children's understandings and interpretations of animals, during visits to zoos and natural history museums, little attention has been given to children's informal encounters and knowledge of everyday plants and animals. Children's informal observations and interactions within their local community form part of their real world knowledge concerning biological phenomena (Gelman 2009). This study shows that English and USA children learn about plants and animals in their everyday lives, some of them exotic, but many are endemic or domesticated pets. These personal observations are often

\section{3}

638

J Sci Educ Technol (2011) 20:630-642 
Table 2 Total number of plants named in 1 min placed into scientific classification

Scientific classification

Age of students Bryophytes VascularSeedless Gymnosperms Monocots

Dicots Total

Country

USA

4 years 6 years 8 years 10 years Total 0000000134

England

00011148619151012285152236787244055

01258112049554231918294911529253961

4 years 6 years 8 years 10 years Total

$\mathrm{N}=9$ for each age group in each country Table 3 Plants named when students were asked for specific plants and where they were seen

Description of animal

Age of Students In the garden/yard Insideyourhouse Outside your house Lives in wet places Livesonwater Livesinwater Lives in the ground

Where plants were seen Zoo Media Store

School Outside Home/garden/yard Visit to natural area (beach, park, woods, etc.)

$\mathrm{N}=9$ for each age level in each country

Country

USA England

4 years 6 years 8 years 10 years 4 years 6 years 8 years 10 years 026913750012213703281547 00110026011212170011143600010028

USA England 4 years 6 years 8 years 10 years 4 years 6 years 8 years 10 years 00000000 0001011601120120011285491124546716790999 
15

\section{4}

often than children in the USA. However, children in both countries do not list zoos as places to see plants. This may be due to the perceptions people hold that zoos are places to see animals.

Children in both countries name farm raised plants more than any other group and children mostly see them at home/garden/yard. This may be a consequence of home gardening or that children are most familiar with farm raised plants, because plants are normally included in a meal. Additionally, children's prior experiences with family, in which they ate plants or planted, seemed to make a difference in children's plant knowledge. This is an important finding for teaching plant concepts. When teachers teach about plants it is paramount that they include hands-on interactions such as planting, dissecting

unused in formal science education. Therefore, an impor- tant part of teaching children biological concepts is pro- viding children's misconceptions to the educators who teach the children.

The plant and animal data suggests similar findings in the English and USA children's ability to name plants and animals, but there are also some interesting differences. These differences seem to be culturally influenced. For example, the role zoos play in children's lives seems to differ between the two countries and between plants and animals. Children in England are more likely to name Bryophytes and seedless vascular plants than children in the USA. This finding may show that the local community does play a large part in what children know about plants. Children in England state they see animals at the zoo more

\section{3}

J Sci Educ Technol (2011) 20:630-642

639

Table 4 Total number animals named in 1 min and where they were seen

Category of animals named by children

Age of Students Exotic (to the country) Endemic wild Pets/Domesticated for pleasure 
Farmed Total

Where animals were seen Zoo Media Petshop

School Outside Home/garden/yard Visit to natural area (beach, park, woods, etc.)

Country

USA

4 years $11 \quad 13 \quad 11$

$4 \quad 39$ USA 4 years $12 \quad 222322900000$

$\mathrm{N}=9$ for each age group in each country

6 years $18 \quad 23 \quad 16$

8 years $35 \quad 65 \quad 23$

10 years $25 \quad 48 \quad 17$

England

Total 4 years $8938 \quad 14910 \quad 6710$

6 years $50 \quad 5 \quad 12$

865

146213000115102027623551932

8 years 1058452818251621713286

6 years 1325

8 years $12 \quad 30$

10 years $14 \quad 29$

England Total 4 years

6 years $28 \quad 20$

8 years 1030283255

years Total 121

11134 
30866

1077

$0 \quad 1 \quad 1 \quad 100000100230000000123$

\section{4}

flowers, touching seeds, and comparing real plant parts (not plastic).

This study supports other findings that children have a wide understanding of the animals they encounter in their everyday lives (Palmer 1993; Gelman 2009). Additionally, the USA data supports Kellert and Westervelt's (1981) and Lindemann-Matthies (2005) findings that children are interested in local animals more than national or interna- tional animals. The most commonly named animals in this study are the mouse, dog, and cat. However, based on the data from this study it should not be assumed that the children are more interested in these animals. The children may have free-listed these animals more often, because these animals are seen more often in the child's local

\section{4}

5744

2200

environment. The opposite was true in England. The gir- affe, elephant, and tiger were named most often. In fact, the African elephant represents one of the most familiar and popular animals in the United Kingdom.

English and USA children named farm animals less than any other group of animals. Moreover, the USA children in this study live near farms, but still fail to mention farm animals. This may be a consequence of families no longer maintaining and slaughtering food animals, such as pigs, sheep, chickens, and cows. Due to large scale dairies, chicken houses, and hog farms, children no longer help the family nurture animals as food products. This may point to a disconnect between food and its origin as a result of social changes and is worthy of further study.

110173110132

4615

1721316310

513510634 
years Total 191

616346

141

023510125715

1010

351

8 years $99 \quad 9 \quad 7$

308526

10 years Total $67284622 \quad 217$

2

1

6 years $64 \quad 5 \quad 4$

$\mathrm{N}=9$ for each age group in each country Table 5 Total number of animals named in $1 \mathrm{~min}$ placed into scientific classification

Scientific classification

Age of Students Mammals Birds Reptiles Amphibians Fishes Arthropods (Arachnids) Arthropods (Insects) Mollusks

Annelids

Country

USA

4 years $28 \quad 4 \quad 4$

6 years $41 \quad 8 \quad 6$

8 years $91 \quad 14 \quad 10$

10 years $64 \quad 7 \quad 6$

England

Total 4 years $22454 \quad 332 \quad 264$ 


\section{3}

640 J Sci Educ Technol (2011) 20:630-642

Table 6 Animals named when students were asked for specific animals and where they were seen

Description of animal

Age of Students Flyingbirds Smallmammals Domesticanimals Flying invertebrates Ground dwelling invertebrate Livesinwater Livesonwater Nocturnalanimal

Where animals were seen Zoo Media Petshop

School Outside Home/garden/yard Visit to natural area (beach, park, woods, etc.)

Country

USA England

4 years 6 years 8 years 10 years 4 years 6 years 8 years 10 years 575845781048577746455666 0001365732232324277937891001126734582467

USA England 4 years 6 years 8 years 10 years 4 years 6 years 8 years 10 years 00010011 $1222002400020020110001104277487836674777 \quad 01110011$

$\overline{\mathrm{N}}=9$ for each age level in each country. The England's primary school had a natural area with a pond

Even though the classroom is a place of formal learning, some informal learning must take place for children to learn about plants and animals. This may be accomplished by designing hands-on activities in which the teacher is an active participant. Science education has been pushing teachers to become hands-off and allowing children to be hands-on and minds on in discovering science concepts (Doherty 1992). This study suggests that teachers must be hands-on when developing young children's biological understandings of plants and animals. Children remember plants and animals that have been introduced to them outside of school. The research presented here demon- strates that school does not have a considerable influence on how children understand objects in the natural environment, especially at younger ages. Therefore, when teaching children about plants and animals, teachers need to become hands-on teachers and mentors, who 
work clo- sely with young children.

This study shows that children are in touch with their everyday environment to varying extents, and that rich experiences can greatly contribute to their knowledge about plants and animals. Early childhood and primary teachers need to remember that children are tabula rasa. Children at all ages come to the classroom with their own ideas about and experiences with animals. To provide children with a valuable, effective learning experience within the formal educational setting, teachers need to bring living plants and animals into the classroom.

Children should be allowed to interact with the organisms and ask questions. Additionally, teachers need to utilize the out-of-doors on the school campus, by taking children outside to look at plants and locate organisms such as birds and spiders. This study shows that children say they learn about organisms at home; therefore, teachers may ask children to interact with family members when learning about organisms. Children may be asked to interview parents about their favorite organism or asked to bring in something from their yard (i.e. leaf, twig, grass, insect, etc.). Students may also be interested in sharing experi- ences they have had with their pets (Prokop and Tunnicliffe 2010). Teachers need to use parents, the school grounds, and classroom organisms to elicit children's knowledge and understandings of plants and animals.

\section{References}

Amsel S (2009) What grows there? Sci Child 47(1):44-47 Ascione FR (1992) Enhancing children's attitudes about the humane treatment of animals: generalized to human-directed empathy.

Anthrozoos 5(3):176-191 Askham LA (1976) The effects of plants on classification behavior in an outdoor environment. J Res Sci Teach 13(1):49-54 Atran S, Medin D (2008) The native mind and the cultural

construction of nature. MIT Press, London, England Bahar M, Ozel M, Prokop M, Usak M (2008) Science student

teachers' ideas of the heart. J Baltic Sci Education 7:78-85

\section{3}

J Sci Educ Technol (2011) 20:630-642

641

Bang M, Medin D, Atran S (2007) Cultural mosaics and mental models of nature. Proceedings of 
the National Academy of Sciences 104: 13868-13874

Barman C, Stein M, McNair S, Barman N (2006) Students' ideas about plants and plant growth. Am Biol Teach 68(2):73-79 Bebbington A (2005) The ability of A-level students to name plants.

J Biol Education 32(2):62-67 Bell B (1981) What is a plant? Some children's ideas. NZ Sci Teach

31:10-14 Bell P, Lewenstein B, Shouse A, Feder M (2009) Learning science in

informal environments. National Academies Press, Washington,

DC BGCI (2010a) Unsustainable use of plant species. Retrieved from

http://www.bgci.org/ourwork/Over_exploitation/ BGCI (2010b) Plant species numbers.

Retrieved from http://

www.bgci.org/worldwide/1521/

Boulter C, Tunnicliffe S, Reiss M (2003) Probing children's under- standings of the natural world. In: Lewis J, Magro A, Simmoneaux L (eds) Biology educations for the real world: studentteacher- citizen. Proceedings of the European research in the didactics of biology conference, Toulouse, France. July 12-16

Braund M (1998) Trends in children's concepts of vertebrate and invertebrate. J Biol Education $32: 112-118$

Braund M, Reiss M (eds) (2004) Learning science outside the classroom. Routledge Falmer, New York

Brown R (1958) How shall a thing be called? Psychol Rev 65:14-21 Cardak O (2009) Science students' misconceptions about birds.

Scienctific Res Essay 4(12):1518-1522 Cardak O, Dikmenli M (2009) Student science teachers' ideas about

endangered bird species: hermit ibis, chukar partridge. Asia-

Pacific Forum on Sci Learning Teach 10(1):11 Carey S (1985) Conceptual change in childhood. MIT press,

Cambridge Cooper CL (2008) Botanical knowledge of a group of South Carolina

elementary school students. Ethnobot Res \& Applications

6:121-127 Davenport T, Prusak L (1998) Working knowledge. Harvard Business

School Press, Boston Dikmenli M (2010) Biology students'conceptual structures regarding

global warming. Energy education science and technology part

B: social and educational studies 2:21-38 Doherty P (1992) Getting hands-on science into the 
classroom.

Hands-On Sci 2-3 Dougherty J (1979) Learning names for plants and plants for names.

Anthropol Linguist 21:298-315 Driver R, Squires A, Rushworth P, Wood-Robinson V (1994) Making

sense of secondary science. Research into children's ideas.

Collins Educational, London, England Eagles PFJ, Muffitt S (1990) An analysis of children's attitudes

toward animals. J Environ Education 21(3):41-44 England's National Curriculum (2011)

Council of British Interna- tional Schools. Retrieved from http://curriculum.qcda.gov.uk/

key-stages-1-and-2/index.aspx

Erdogan M, Erentay M (2007) Children's perceptions on endangered species and threatened environments: results from unique and universal project. Proceedings of the 4th International Confer- ence on Hands-on Science. University of Azores, Ponta Delgada, Portugal, July 23-27

Eshach H (2006) Science literacy in primary and pre-schools. Springer, The Netherlands

Evans S, Garside C, Gebbels S, Stockill J, Green M (2007) The 'citizens' day: encouraging young people to acquire, value and use environmental knowledge. School Sci Rev 88(325): 4550

Falk J, Dierking L (2010) The 95 percent solution: school is not where most Americans learn science. American scientist update 7(10),

Retrieved from http://www.americanscientist.org/my_amsci/

enews/qGAc1hrXVEM=

Fraser B, Tobin K (1998) International handbook of science education, volume I. Kluwer Academic Press, London, England Fujiwara T, Matoh T (2009) Plant nutrition — roots of life for fundamental biology and better crop production. Plant and Cell

Physiol 50(1):2-4 Gatt S, Tunnicliffe S, Borg K, Lautier K (2007) Young Maltese

children's ideas about plants. J Biol Education 41(3):117-121 Gelman S (2009) Learning from others: children's construction of

concepts. Annual Rev Psychol 60:115-140 Haslam F, Treagust DF (1987) Diagnosing secondary students'

misconceptions of photosynthesis and respiration in plants using

a two-tier multiple choice instrument. J Biol Educ 21(3):203-211 Helm H, Novak J (1983)

Proceedings of the international seminar on misconceptions in science and mathematics.

Department of 
Education, Cornell University, Ithaca. June 20-25 Hershey D (1996) A historical perspective on problems in botany

teaching. Am Biol Teacher 58(6):340-347 Jaakkola R, Slaughter V (2002) Children's body knowledge: under-

standing 'life' as a biological goal. British J Dev Psychol 20(3):

325-342 Jones M (2009) The gift of the tree. Sci Child 47(1):40-43 Keil FC (1979) Semantic and conceptual development. An ontolog-

ical perspective. Harvard University Press, London, England Keiler L, Woolnough B (2002)

Practical work in school science: the

domininance of assessment. School Sci Rev 83(304):83-88 Kellert SR (1980) Phase II: activities of the American public relating to animals. United States department of the interior fish and

wildlife service Kellert SR, Westervelt MO (1981) Trends in animal use and

perception in twentieth century America: Phase IV. United

States department of the interior fish and wildlife service Kose S (2008) Diagnosing student misconceptions: using drawings as

a research method. World Appl Sci J 3:283-293 Krueger B, Loughran J, Duit R (2002)

Constructivism. In: Wallace J, Louden W (eds) Dilemmas of science teaching. Routledge

Falmer, London, England LaHart DE (1978) The influence of knowledge on young people's

perceptions about wildlife. Doctoral Dissertation. Florida State

University, College of Education Lindemann-Matthies P (2005) 'Loveable' mammals and 'lifeless'

plants: how children's interest in common local organisms can be enhanced through observation of nature. Int J Sci Education 27(6):655-677

Louv R (2006) Last child in the woods: saving our children from nature-deficit disorder. Algonquin Books, Chapel Hill

Lucas A (1991) Info-tainment and informal sources for learning science. Int J Sci Education 13(5):495-504

Metz K (2010) Scaffolding children's understanding of the fit between organisms and their environment in the context of practices of science. Proceedings of the 9th international conference of the learning sciences, Chicago

Nabhan G, St. Antoine S (1993) The loss of floral and faunal story: the extinction of experience.In: Kellert S, Wilson EO (eds) The biophilia hypothesis. Island Press, Washington

Natarajan C, Chunawala S, Apte S, Ramadas J (2002) Lessons for teaching botany: what middle school students know about plants. In: Rethinking science and technology education to meet the 
demands of future generations in a changing world. International Organization for Science and Technology Education (IOSTE) Symposium Proceedings. Parana, Brazil. July 28-August 2

National Research Council (1996) National science education stan- dards. National Academies Press, Washington

Nonaka I, Takeuchi H (1995) The knowledge creating company. Oxford University Press, New York

\section{3}

642

J Sci Educ Technol (2011) 20:630-642

Novak JD (1990) Concept maps and Vee diagrams: two metacogni- tive tools for science and mathematics education. Instructional Sci 19:29-52

Novak J, Gowin D (1984) Learning how to learn. Cambridge University Press, New York

O'Brien CM (2008) Ethnobiological knowledge in the Sonoran desert: identifying intergenerational learning and variation. Ph.D. dissertation. University of Georgia, Athens, Georgia

Osborne R, Wittrock M (1983) Learning science: a generative approach. Sci Education 67:489_ 508

Osborne J, Wadsworth P, Black P (1992) Processes of life, primary SPACE project research report. University of Liverpool, Liver- pool, England

Osborne J, Driver S, Simon S (1998) Attitudes to science: issues and concerns. School Sci Rev 79(288):27-33

Palmer J (1993) Development of concern for the environment and formative experiences of education. J Environ Education 24(3):26-30

Pergams O, Zaradic P (2006) Is love of nature in the US becoming love of electronic media? 16year downtrend in national park visits explained by watching movies, playing video games, internet use, and oil prices. J Environ Manage 80:387-393

Piaget J (1983) The child's conception of the world. Rowman \& Allanheld, Totowa

Population Connection (2010) [Graph Illustration Current Population of the World and US October 1, 2010]. Retrieved from http:// www.populationconnection.org/site/PageServer

Prokop P, Fanoviova' J (2006) Students' ideas about the human body: do they really draw what they know? J Baltic Sci Education 2:86-95

Prokop P, Rodak R (2009) Ability of Slovakian pupils to identify birds. Eurasia J Mathematics Sci \& Technol Education 5(2):127-133 
Prokop P, Tunnicliffe S (2008) “Disgusting”’ animals: primary school children's attitudes and myths of bats and spiders. Euroasia J Mathematics Sci \& Technol 4(2):87-97

Prokop P, Tunnicliffe S (2010) Effects of having pets at home on children's attitudes toward popular and unpopular animals. Anthrozoos 23(1):21-35

Prokop P, Tuncer G, Chuda' J (2007) Slovakian students' attitude toward biology. Eurasia J Mathematics Sci \& Technol Education 3(4):287-295

Prokop P, Prokop M, Tunnicliffe S (2008) Effects of keeping animals as pets on children's concepts of vertebrates and invertebrates. Int J Sci Education 30:431-449

Prokop P, Fanoviova' J, Kubiatko M (2009) Vampires are still alive: Slovakian students'attitudes toward bats. Anthrozoos 22:19-30

Quinones C, Jeanpierre B (2005) Planting the spirit of inquiry. Sci and Child 42(7):32-35

Reiss M, Tunnicliffe S (1999) Conceptual development. J Biol Education 34(1):13-16

Reiss M, Tunnicliffe S (2001) Students' understandings of human organs and organ systems. Res Sci Education 31:383-399 Reiss M, Tunnicliffe S, Andersen A, Bartoszeck A, Carvalho G, Chen

S, Jarman R, Jonsson S, Manokore V, Marchenko N, Mulemwa J, Novikova T, Otuka J, Teppa S, Rooy W (2002) An international study of young peoples' drawings of what is inside themselves. J Biol Education 36:58-64

Reiss M, Boulter C, Tunnicliffe S (2007) Seeing the natural world: a tension between pupils' diverse conceptions as revealed by their visual representations and monolithic science lessons. Visual Communciation 6(1):99-114

Richardson G, Blades D (2001) Social studies and science education: developing world citizenship through interdisciplinary partner- ships. Can Soc Stud 35(3):12-25

Rosch E, Mervis C (1975) Family resemblances: studies in the internal structures of categories. Cognitive Psychol 7:573-605

Russell T, Watt D (1990) Growth: primary science research reports. University Press, Liverpool, England

Sanders D (2007) Making public the private life of plants: the contribution of informal learning environments. Int J Sci Education 29(10):1209-1228

Sato M, James P (1999) Nature and environment as perceived by university students and their supervisors. Int J Environ Education Inf 18:165-172

Schneekloth L (1989) Where did you go? "The forest". "What did you see?" Nothing. Child Environ Q 6(1):14-17

Shepardson D (2002) Bugs, butterflies, and spiders: children's understandings about insects. Int J Sci Education 24:627-643

Solomon J (1987) Social influences on the construction of pupils' understanding of science. Stud 
Sci Education 14:63-82

Stavy R, Wax N (1989) Chidlren's conception of plants as living things. Hum Dev 32:88-94

Strgar J (2007) Increasing the interest of students in plants. J Biol Education 42(1):19-23

Tanner L (1980) Significant life experiences. A new research area in environmental education. J Environ Education 11(4):20-24 Teixeira F (2000) What happens to the food we eat? Children's

conceptions of the structure and function of the digestive system.

Int J Sci Education 22:507-520 Toplis R, Cleaves A (2006) Science investigations: the views of 14 to

16 year old pupils. Res Sci and Technol Education 24(1):69-85 Torkar G, Bajd B (2006) Trainee teachers' ideas about endangered

\section{3}

Tull

birds. J Biol Education 41:5-8 D (1992) Social constructivism: botanical classification schemes of elementary school children. Paper presented at the Annual Meeting of the American

Educational Research Association. San Francisco, CA. April 20-24

Tunnicliffe S (1996) The relationship between Pupil's ages and the content of conversations generated at three types of animal exhibits. Res Sci Education 26(4):461-480

Tunnicliffe S (1999) Science out of the classroom. Proceedings of the 23rd Annual Meeting of the Japanese Society for Science Education, 72-74

Tunnicliffe S (2001) Talking about plants-comments of primary school groups looking at plants as exhibits in a botanical garden. J Biol Education 36:27-34

Tunnicliffe S, Reiss M (1999) Building a model of the environment: how do children see animals. J Biol Education 33(4):142-148

Tunnicliffe S, Reiss M (2000) Building a model of the environment: how do children see plants? J Biol Education 34(4):172-177

Tunnicliffe S, Boulter C, Reiss M (2007) Pigeon friend or foe? Children's understandings of an everyday animal. Paper pre- sented at the British Educational Research Association Annual Conference. Institute of Education, University of London. September 12-15

Tunnicliffe S, Gatt S, Agius C, Pizzuto S (2008) Animals in the lives of young Maltese children. Eurasia J Mathematics Sci \& Technol 4(3):215-221

Uno G (2009) Botanical literacy: what and how should students learn about plants? Am J Biol 96:1753-1759

Vadala C, Bixler R, James J (2007) Childhood play and environmental interest: panacea or snake 
oil? J Environ Education 39:1-17 Wagner G (2008) Botanical knowledge of a group of college students

in South Carolina. USA Ethnobot Res \& Appl 6:443-458 Wandersee J, Schussler E (2001)

Toward a theory of plant blindness.

Plant Sci Bull 17(1):2-9 Westervelt MO, Llewellyn LG (1985) Youth and wildlife. U.S.

Department of Interior, Fish and Wildlife Service. U.S. Gov-

ernment Printing Office, Washington, DC Zaradic A, Pergams O (2007) Videophilia:

implications for childhood

development and conservation. J Dev Processes 2(1):130-144

Copyright of Journal of Science Education \& Technology is the property of Springer Science \& Business Media B.V. and its content may not be copied or emailed to multiple sites or posted to a listserv without the copyright holder's express written permission. However, users may print, download, or email articles for individual use. 